\title{
Factors associated with the functional capacity of elderly individuals with hypertension and/or diabetes mellitus
}

\author{
Fatores associados à capacidade funcional de pessoas idosas com hipertensão e/ou diabetes mellitus \\ Factores asociados a la capacidad funcional de ancianos con hipertensión y/o diabetes mellitus
}

\author{
Thaciane Alves Mota $^{1}(1)$ \\ Manuela Bastos Alves ${ }^{1,2}$ (D) \\ Valdenir Almeida da Silva ${ }^{3}$ (D) \\ Francieli Aparecida de Oliveira ${ }^{1}$ (D) \\ Priscilla Mécia Conceição de Brito $^{2}$ (1) \\ Rudval Souza da Silva ${ }^{1,2}$ (D)
}

1. Universidade Federal da Bahia, Programa de Pós-graduação em Enfermagem e Saúde. Salvador, BA, Brasil.

2. Universidade do Estado da Bahia.

Senhor do Bonfim, BA, Brasil.

3. Hospital Universitário Professor Edgard

Santos. Salvador, BA, Brasil.
Corresponding author:

Rudval Souza da Silva.

E-mail:rudsouza@uneb.br

Submitted on $03 / 23 / 2019$.

Accepted on 09/04/2019.

DOI: 10.1590/2177-9465-EAN-2019-0089

\begin{abstract}
Objective: To identify the association of sociodemographic and clinical factors with the functional capacity of elderly individuals with hypertension and/or diabetes mellitus. Method: An outpatient, non-probabilistic cross-sectional study, performed in two Health Units in a city from the inland of Bahia, Brazil, with a population of 100 elderly individuals monitored through the HIPERDIA Program. Data was collected using a questionnaire covering socio-demographic data, the Katz index and the Mini Mental State Examination. Results: The analysis showed that $45 \%$ of the respondents had some degree of dependence. In the multivariate analysis it as observed that the elderly individuals aged 70 years old or more presented 1.9 times more chances to develop some degree of dependence in relation to those under 70 years old. Considered the same age group, it was shown that those with concomitant comorbidities (hypertension and diabetes) were 1.7 times more likely to develop some dependence compared to those who only had hypertension. Conclusion and implications for practice: It was possible to conclude that functiona capacity as a multifactorial condition in this population was determined by age and by the presence of comorbidities (hypertension and diabetes). Identifying these disability-conditioning factors allows for a better planning of nursing care based on promoting a healthy, independent and autonomous aging process.
\end{abstract}

Keywords: Frail elderly; Dependent senior citizen; Chronic diseases; Family Health Strategy.

\section{Resumo}

Objetivo: Identificar a associação de fatores sociodemográficos e clínicos à capacidade funcional de pessoas idosas com hipertensão e/ou diabetes mellitus. Método: Estudo transversal, de base ambulatorial e não probabilístico, realizado em duas Unidades de Saúde de um município do interior da Bahia, Brasil, com uma população de 100 idosos acompanhados no Programa HIPERDIA. Os dados foram coletados a partir de questionário contemplando dados sociodemográfico, o Index de Katz e o Mini Exame do Estado Mental. Resultados: 45\% dos entrevistados apresentaram algum grau de dependência. Na análise multivariada observou-se que os idosos com 70 anos ou mais apresentam 1,9 vezes mais chances de desenvolver algum grau de dependência em relação aos menores de 70 anos. Considerado o mesmo recorte etário, aqueles que possuem comorbidades concomitantemente (hipertensão e diabetes) apresentam 1,7 vezes mais chances de desenvolverem alguma dependência em relação àqueles que possuem apenas hipertensão. Conclusão e implicações para a prática: Dos resultados foi possivel concluir que a capacidade funcional como condição multifatorial, nesta população, foi determinada pela idade $e$ presença de comorbidades (hipertensão e diabetes). Identificar esses fatores que condicionam a incapacidade possibilita um melhor planejamento da assistência de enfermagem pautada na promoção de um processo de envelhecimento saudável, independente e autônomo.

Palavras-chave: Idoso fragilizado; Idoso Dependente; Doenças crônicas; Estratégia Saúde da Família.

\section{Resumen}

Objetivo: Identificar la asociación de factores sociodemográficos y clínicos con la capacidad funcional de ancianos con hipertensión y/o diabetes mellitus. Método: Estudio transversal, no probabilístico y ambulatorio realizado en dos Unidades de Salud de un municipio del interior de Bahía, Brasil, con una población de 100 personas mayores monitoreadas a través de Programa HIPERDIA. Los datos se recolectaron utilizando una encuesta en la que se contemplaron datos sociodemográficos, el índice de Katz y el mini examen de Estado mental. Resultados: El análisis demostró que el $45 \%$ de los encuestados presentaron algún grado de dependencia. En el análisis multivariado, se observó que los ancianos de al menos 70 años de edad presentan 1,9 veces más probabilidades de desarrollar algún grado de dependencia en relación a los menores de 70 años. Considerada la misma franja etaria, se evidenció que aquellos que poseen comorbilidades concomitantes (hipertensión y diabetes) presentan 1,7 veces más probabilidades de desarrollar alguna dependencia en relación a aquellos que solo padecen hipertensión. Conclusión e implicaciones para la práctica: A partir de los resultados se pudo concluir que la capacidad funcional como condición multifactorial, en esta población, quedó determinada por factores como la edad y la presencia de comorbilidades (hipertensión y diabetes). Identificar estos factores que condicionan la incapacidad hace posible planificar mejor la asistencia de enfermería pautada en la promoción de un proceso de envejecimiento sano, independiente y autónomo.

Palabras clave: Anciano debilitado; Persona mayor dependiente; Enfermedades crónicas; Estrategia de Salud Familiar 


\section{INTRODUCTION}

Aging causes important changes not only in the population age structure, but also in its epidemiological profile. As the population ages, a chronic noncommunicable diseases (CNDs) scenario predominates, which can lead to impairments in the functional and cognitive capacity of the elderly. ${ }^{1,2}$ In this perspective, aging is a life period surrounded by physical, psychological and social changes that affect each individual in a unique way. ${ }^{3}$

Advancing in age can also cause important physiological changes, such as decreased aerobic capacity, muscle strength, balance and flexibility, implying limitations in the range of motion. These effects hinder the functionality of the elderly, affecting their functional capacity to perform activities of daily living (ADLs). ${ }^{4}$

People who live longer are more likely to develop CNDs, which can lead to functional and, consequently, economic and family dependence. The prevalence of some of these diseases increases from the age of 60 onwards, especially osteoarticular diseases, systemic arterial hypertension (SAH), cardiovascular diseases, diabetes mellitus (DM), chronic respiratory diseases, cerebrovascular disease and cancer. ${ }^{5,6}$

In Brazil, chronic diseases constitute a major public health problem and account for $72 \%$ of the causes of death. Among most common CNDs in old age are SAH and DM which, when associated, are considered as the main risk factors for renal complications, heart and cerebrovascular diseases development, representing high socioeconomic costs and to the health system, resulting from accompanying complications. ${ }^{7}$

In an individual with multiple chronic diseases, the inability to perform one or all ADLs may be related to only a single morbidity condition or to the independent effect of several conditions, each one affecting only certain activities. In addition, sociodemographic factors such as age, gender, education, income, among others can significantly influence functional capacity of elderly people. . $^{8}$

The International Classification of Functioning, Disability and Health (ICF), a World Health Organization (WHO) taxonomy, presents a definition of disability as a broad term which enfolds the commitments and limitations of activity or restrictions in a person's life to involve a dynamic interaction between health conditions (illness, injury, trauma, etc.) and contextual factors (personal and environmental attributes). ${ }^{10}$

There are several ways to assess the ability and/or functional disability of elderly people. In epidemiological studies, the ability to perform basic activities of daily living (BADLs) and/or instrumental activities of daily living (IADLs) is often considered. The first is related to the performance of self-care tasks such as bathing and eating, and the second one is about more complex activities such as shopping and transportation for mobility. ${ }^{11}$

According to the $\mathrm{WHO}$, all countries have been warned that by 2020 there will be an increase in the causes of death and disability worldwide. On this perspective, understanding the factors that contribute to the functional disability of the elderly is important to provide subsidies which may contribute to the elaboration of more effective prevention strategies, capable of maintaining in an independently way the functionality of these individuals or delaying the arrival of limitations. ${ }^{12-13}$

Given this scenario, it is considered relevant to study what has contributed to the cases of functional disability in the elderly, hoping to contribute to the planning of actions by the nurse who works in the primary health care scenario, in search of correct interventions, aiming to assist in the promotion of quality of life of these elderly individuals and in the reorganization of the health strategies in the community by supporting these elderly and their families/caregivers.

The present study aimed to identify the association of sociodemographic and clinical factors to the functional capacity of elderly people with hypertension and/or diabetes mellitus.

\section{METHOD}

This is a cross-sectional non-probabilistic study with an ambulatory base, conducted in two Health Units located in a municipality in the inland of the state of Bahia, Brazil. One of the chosen units works with a team from Community Health Agents (CHAs) Program and a Family Health Strategy (FHS) team, and the other, only with an FHS team. Both units were selected because they attend to the largest elderly public, about $45 \%$ of the total elderly with a medical diagnosis of SAH and/ or DM, registered and followed in the HIPERDIA Program and for covering the neighborhoods that have the largest number of elderly people receiving social benefit - "Bolsa Familia" and "Benefício de Prestação Continuada" - which shows that these individuals are more economically disadvantaged when compared to other residents. The selected municipality has 15 Basic Health Units between the CHAs and the FHS.

The sample was for convenience and included 100 elderly individuals. For sample calculation, a $5 \%$ of maximum desired error, a 95\% confidence level and possible refusal losses were considered. 142 elderly individuals suffering from SAH and/or DM were registered and followed-up in these two selected units. The sample size was initially calculated in 104 elderly individuals. Losses totaled four individuals, three due to refusal to participate in the study and one due to an address change.

Data collection was performed from January to March 2016, when the home visit was performed, in a private place, according to the availability of the participants, with the application of a questionnaire including sociodemographic data which included variables such as gender, age, education, marital status, presence of comorbidities; the Katz Index, which deals with the assessment of Basic Activities of Daily Living (BADLs) and the Mini Mental State Examination (MMSE), which allows for a cognitive pattern assessment and was applied to assess whether these elderly people had preserved their cognitive function, demonstrating ability to respond to the data production instrument. 
Inclusion criteria were defined as being 60 years of age or older, being under follow-up at the reference Health Unit and during MMSE application reaching a score above 18 points for the non-literate elderly and 24 points for the literate. And, as exclusion criteria, elderly individuals whose MMSE score was lower than the previously mentioned, because scores below 18 or 24 points may be suggestive of dementia, thus compromising the reliability of the data if the collection instrument was applied. All participants voluntarily agreed to collaborate with the study and signed the Free Informed Consent Form (FICF).

Data was analyzed using the Epi-Info ${ }^{\circledR}$ software, version 6.04 (CDC, USA) and the variable of functional capacity was considered as the outcome. To verify its association with other variables, the Fisher's Exact Test was performed, considering a significance level of $p<0.05$. The logistic regression was performed using the Poisson regression model with robust variance. Initially, the gross Relative Risk (RR) was evaluated by observing each covariable separately and then the $R R$ was adjusted to observe all co-variables simultaneously, with a confidence interval of $95 \%$.

The Poisson Regression model allows controlling possible confounding variables, highlighting only those that can modify the chance of developing some degree of dependence. For this analysis it was considered that, when $p<0.05$, there would be evidence that this co-variable affected the onset/development of some degree of dependence. For the RR of each co-variable, it was considered that, when it was $>1$, that co-variable would increase the chance of the outcome (dependence), and when $<1$ the co-variable would act as a protective factor against the outcome (dependence). The RR was considered statistically significant only when the Confidence Interval did not include the value 1 within its limits.

The study was approved by the Research Ethics Committee under opinion number 1,283,150/2015 and complied with the formal requirements contained in Resolution No. 466 of December $12^{\text {th }}, 2012$, which regulates research involving human subjects.

\section{RESULTS}

From the total study participants, $65 \%$ are female, $52 \%$ of them being 70 years of age or older, with a mean of 72.68 years old. Regarding schooling, there was a prevalence of elderly individuals who declared themselves literate (32\%). With regard to marital situation, a population of widowers prevailed (48\%) and, regarding to the presence of comorbidities, a prevalence of elderly suffering from SAH (57\%) was evidenced (Table 1).

The percentage values of the variables distribution related to the BADLs are presented in Table 1, which were extracted after the application of the Karts Index, where $45 \%$ of the respondents demonstrated some degree of dependence to perform such activities.

According to the multivariate analysis, two variables stood out: elderly people aged 70 years old and over who are approximately 1.9 times more likely to have some degree of dependence in comparison to those between 60 and 69 years old; and elderly people with concomitant SAH and DM are approximately 1.7 times more likely to develop some degree of dependence than those who only have SAH (Table 2).

\section{DISCUSSION}

Regarding the study participants, a prevalence of females $(65 \%)$ was observed, which is thought to be a gender issue in which women have a greater sought of health services. A similar study, conducted in an FHS unit in a city in the Federal District, revealed similar data in which $65 \%$ of the investigated people were also female and had some comorbidity. ${ }^{14}$ According to the latest Demographic Census conducted by the Brazilian Institute of Geography and Statistics (Instituto Brasileiro de Geografia e Estatística, IBGE) $51.4 \%$ of all elderly people are female, ${ }^{15}$ thus characterizing the phenomenon of feminization of old age resulting from the decrease in the mortality rate among women in relation to men.

Regarding the age group, $52 \%$ of the participants are aged 70 years old or older, and the mean value found in this study was 72.68 years old. A similar study, conducted in a large municipality in the inland of Paraíba, showed that the prevalence of functional disability was higher among elderly people belonging to older age groups: $\geq 72$ years old. ${ }^{16}$ Advancing in age, significant changes in the individual's physiology may occur, leading to a decrease in the individual's motor and/or cognitive ability and, consequently, to dependence on basic activities of self-care..$^{9,10,16}$

Although $32 \%$ of the participants reported being literate and $30 \%$ without schooling, the participants had a low education level, only $38 \%$ of them having completed elementary or high school. In a research ${ }^{16}$ conducted in a health unit in the capital city of São Paulo, with 420 elderly individuals, the relative number of elderly who declare no education was $48 \%$ followed by those with incomplete elementary school (52\%).

The low level of schooling found among the participants of this research may be justified based on IBGE data, ${ }^{5}$ reference year 2010, which highlights that the average time of study of the Brazilian elderly is 3.9 years, with $32 \%$ remaining less than 1 year in school. This represents an unfavorable social condition that negatively influences access to the health services as well as the perception that these individuals have about the disease, the importance of treatment, control and in self-care. ${ }^{11}$

Regarding marital status, it was observed that $48 \%$ of the interviewed elderly women are widows, a condition that leads these elderly women to live mostly alone. Thus, this absence of a partner can lead to isolation and less health care, leading to the non-monitoring of chronic diseases and to a greater risk for the development of functional disability. This same situation was detected in the aforementioned study conducted in the countryside side of Paraíba. ${ }^{16}$ 
Table 1. Sociodemographic variables, presence of comorbidities and frequencies related to BADLs in the elderly. Senhor do Bonfim, BA, Brazil. 2016. N=100

\begin{tabular}{|c|c|c|}
\hline \multirow[b]{2}{*}{ Variables } & \multicolumn{2}{|c|}{$n=100$} \\
\hline & No. $(\%)^{1}$ & $\begin{array}{c}\text { Mean (SD) } \\
\text { Median (IQR) }\end{array}$ \\
\hline \multicolumn{3}{|l|}{ Gender } \\
\hline Female & $65(65 \%)$ & \\
\hline Male & $35(35 \%)$ & \\
\hline Age & & 72.68 \\
\hline 70 years old or more & $52(52 \%)$ & \\
\hline 60 to 69 years old & $48(48 \%)$ & \\
\hline \multicolumn{3}{|l|}{ Schooling } \\
\hline No schooling & $30(30 \%)$ & \\
\hline Literate & $32(32 \%)$ & \\
\hline Primary/High School Education & $38(38 \%)$ & \\
\hline \multicolumn{3}{|l|}{ Marital status } \\
\hline Married & $44(44 \%)$ & \\
\hline Widow/Widower & $48(48 \%)$ & \\
\hline Single/Divorced & $8(8 \%)$ & \\
\hline \multicolumn{3}{|l|}{ Presence of comorbidities } \\
\hline Systemic Arterial Hypertension & $57(57 \%)$ & \\
\hline Diabetes Mellitus & $20(20 \%)$ & \\
\hline Systemic Arterial Hypertension/Diabetes Mellitus & $23(23 \%)$ & \\
\hline Basic Activities of Daily Living Independent & $55(55 \%)$ & \\
\hline Female & $36(65 \%)$ & \\
\hline Male & $19(35 \%)$ & \\
\hline Some dependence degree of & $45(45 \%)$ & \\
\hline Female & $17(38 \%)$ & \\
\hline Male & $28(62 \%)$ & \\
\hline
\end{tabular}

${ }^{1}$ Number/Percentage; ${ }^{2}$ Standard Deviation and interquartile.

Table 2. Risk factors for independence or some degree of dependence on elderly people. Poisson Regression with robust variance. Senhor do Bonfim, BA, Brazil. 2016. $\mathrm{N}=100$

\begin{tabular}{|c|c|c|c|c|c|c|c|c|}
\hline \multirow[b]{2}{*}{ Co-variables } & \multirow[b]{2}{*}{ Gross RR* } & \multicolumn{2}{|c|}{ 95\% Confidence Interval } & \multirow[b]{2}{*}{ P-value } & \multirow{2}{*}{$\begin{array}{c}\text { Adjusted } \\
\mathrm{RR}^{* *}\end{array}$} & \multicolumn{2}{|c|}{ 95\% Confidence Interval } & \multirow[b]{2}{*}{ P-value } \\
\hline & & $\begin{array}{c}\text { Lower } \\
\text { Limit }\end{array}$ & Upper Limit & & & $\begin{array}{c}\text { Lower } \\
\text { Limit }\end{array}$ & Upper Limit & \\
\hline Age ( $\geq 70$ years old) & 2.044 & 1.247 & 3.351 & 0.005 & 1.897 & 1.132 & 3.18 & 0.0152 \\
\hline Gender (Female) & 0.737 & 0.481 & 1.128 & 0.160 & 0.743 & 0.465 & 1.19 & 0.2144 \\
\hline Widow/Widower & 1.348 & 0.850 & 2.137 & 0.200 & 1.127 & 0.683 & 1.86 & 0.6396 \\
\hline Single/Divorced & 0.971 & 0.368 & 2.558 & 0.950 & 0.711 & 0.311 & 1.62 & 0.4170 \\
\hline DM & 1.221 & 0.676 & 2.208 & 0.508 & 1.167 & 0.664 & 2.05 & 0.5905 \\
\hline SAH/DM & 1.770 & 1.126 & 2.783 & 0.013 & 1.662 & 1.053 & 2.62 & 0.0292 \\
\hline Literate & 1.062 & 0.655 & 1.723 & 0.806 & 1.212 & 0.744 & 1.97 & 0.4404 \\
\hline $\begin{array}{l}\text { Primary/High School } \\
\text { Education }\end{array}$ & 0.684 & 0.388 & 1.207 & 0.190 & 0.845 & 0.494 & 1.45 & 0.5388 \\
\hline
\end{tabular}

* Gross Relative Risk; ** Adjusted Relative Risk. 
The aging process and the age-related chronic diseases can overload the public health system and the family, since they compromise the individual's autonomy and affect their functional capacity. Social, economic and demographic aspects such as income, schooling, gender, age and marital status and the presence of chronic diseases such as SAH and DM have been identified as compromising factors for the functional capacity in this population. ${ }^{14}$

Regarding the presence of comorbidities, $57 \%$ of the respondents report suffering from SAH and $23 \%$ of them have concomitant SAH and DM, which is common in this age group. This reality was also found in a study conducted with 150 elderly individuals in a municipality in the inland of Bahia, where it was found that a percentage of $21.5 \%$ of the participants suffer from DM and $40.8 \%$, from SAH. ${ }^{8}$

Among the most cited chronic diseases in current research studies, SAH and DM are the most prevalent among the elderly population. ${ }^{14}$ Recent studies conducted in a city in the state of Minas Gerais, signals that there is a significant influence of chronic diseases on functional capacity and, among these diseases, cardiac, pulmonary, SAH and arthropathy have negative consequences for the functionality of the elderly. ${ }^{17}$

In the univariate analysis using the gross relative risk, and in the multivariate analysis using the adjusted relative risk, the variables age ( $\geq 70$ years old) and presence of comorbidities (SAH/DM) were associated with some degree of dependence for the functional capacity. According to the multivariate analysis, older women aged $\geq 70$ years old have approximately 1.9 a chance of having some degree of dependence compared to those aged 60 to 69 years old. It is an even small rate compared to another similar study, ${ }^{13}$ which demonstrated that the age group $\geq 70$ years old had a prevalence of functional disability 2.47 times higher compared to the elderly under 70 years old.

An investigation conducted in a city in the inland of Minas Gerais, using the same variables, also showed that most elderly people under 75 years old reported that they had no difficulty performing activities of daily living. This proportion statistically decreased in the elderly over 80 yearsold. ${ }^{17}$

Dependence on BADLs among elderly people is differentiated between sociodemographic groups, with a higher prevalence found in those with unfavorable sociodemographic conditions. ${ }^{11}$ The functional capacity impairment observed in older people in this study is also found in the national and international literature. ${ }^{12,13}$

In Campina Grande, Paraíba, a study found that there is a direct relationship between prevalence of functional disability and age. Elderly individuals aged 80 years old or older had a 3.19 times higher prevalence of developing functional disability when compared to those aged 60 to 69 years old. ${ }^{17}$ Data analyzed in Avaré, São Paulo, further demonstrate that the age group between 60 and 69 years old appears as a protective factor for functional dependence. ${ }^{18}$
Advancing in age, various physiological systems gradually decline, including the nervous and the muscle-skeletal ones, which are essential for performing certain basic activities such as bathing, dressing, going to the bathroom, lying down, and getting out of bed or chair, eating alone, combing, cutting toenails, or climbing stairs. Older seniors are more likely to have functional limitations to perform simpler activities, such as those of self-care. From this perspective, population longevity, if associated with functional disability, will have a greater impact on health services. ${ }^{17}$

The risk of becoming dependent for the BADLs is higher among people over 80 years old compared to those aged 60 to 69 years old. These data help understand the changes that are occurring in the aging process and alert to the possible negative impacts, on the dependence and autonomy of the elderly.

Concerning the presence of comorbidities, elderly individuals over 70 years old who have both SAH and DM present approximately 1.7 times a chance of developing some degree of dependence than those who only have $\mathrm{SAH}$ and are below 70 years old.

Contrary to these data, it is worth highlighting a survey conducted with elderly people in the city of São Paulo, which showed different results when concluding that the highest chance, about 1.9 times, of developing functional disability was among individuals aged 65 to 69 years old. ${ }^{19}$

The reduction in the functional capacity is directly associated with the presence of hypertension, cardiovascular disease and stroke sequela. ${ }^{20} \mathrm{~A}$ study conducted in the city of São Paulo found that the presence of hypertension increases by $39 \%$ the chance of elderly people becoming dependent for the BADLs and that heart disease, arthropathy, and lung disease increase by $82 \%$, $59 \%$, and $50 \%$, respectively, the chances of these individuals developing dependence. ${ }^{19}$ Diabetes mellitus alone did not have a statistically significant relationship with dependence for the activities of daily livin, ${ }^{14}$ corroborating with the data described in Table 2 .

Currently, there is a tendency for an increasing number of elderly people with SAH to develop DM, since SAH is considered a risk factor for the development of DM. The concomitant presence of these two chronic diseases is directly related to a greater development of functional disability for self-care functions, leading the elderly to a more vulnerable condition. ${ }^{21}$

Although in this research the presence of DM was not associated with any degree of dependence, a research study conducted in the city of Lafaiete Coutinho, Bahia, showed that suffering from DM significantly increases the chances of the elderly becoming dependent for both BADLs and IADLs since this comorbidity causes an accelerated cognitive deterioration through the early aging of the central nervous system. ${ }^{22}$

Some studies also bring about associations of quality of life with chronic diseases and show that elderly people with comorbidities tend to learn to live with several limitations in their daily lives, since the disease requires adaptation of the patient and family in different aspects of life. This adaptation possibly implies a decrease in quality of life..$^{23}$ 
Other variables such as gender, marital status and schooling level did not present a significant association for the development of dependence among elderly people, although some studies present statistically significant associations between these variables and functional capacity.

The research results contribute to the sedimentation of knowledge about morbidity characteristics among elderly Brazilians seeking the HIPERDIA Program. Attention is drawn to the fact that, among the surveyed population, there is a decline in the capacity among the elderly and those with more than one comorbidity. Thus, such findings may support the targeting of preventive nursing and multi-professional actions for this public in order to minimize or delay negative effects on the performance of BADLs and IADLs.

\section{CONCLUSION AND IMPLICATIONS FOR PRACTICE}

The evidence presented in this study shows that functional capacity can be influenced by sociodemographic and epidemiological factors, thus proving to be a multi-factorial condition. According to the associated variables with functional capacity such as age, gender, schooling, marital status and the presence of comorbidities such as SAH and DM, the elderly aged 70 years old or older, as well as those suffering from SAH and $\mathrm{DM}$, concomitantly, were more likely to develop some degree of dependence for the BADLs.

The study had a limitation at the time of collection because it was performed through home visits, and some elderly individuals were not at home at the time of the visit. Even with this limitation, the number of elderly people interviewed was sufficient for the study to be carried out and relevant.

Identifying these factors that condition disability enables a better planning of nursing care based on the promotion of a healthy, independent and autonomous aging process.

\section{REFERENCES}

1. Organização Mundial da Saúde (OMS). Resumo - Relatório Mundial de Envelhecimento a saúde [Internet]. Genebra: OMS; 2015; [cited 2019 feb 19]; [aprox.30 telas]. Available from: http://www.who.int/about/ licensing/copyright_form/en/index.html

2. Fialho CB, Costa MFL, Giacomin KC, Loyola Filho Al. Capacidade Funcional e uso de serviços de saúde por idosos da Região Metropolitana de Belo Horizonte, Minas Gerais, Brasil: um estudo de base populacional. Cad Saúde Pública [Internet]. 2014 mar; [cited 2017 mar 09]; 3(30):599610. Available from: http://www.scielo.br/pdf/csp/v30n3/0102-311Xcsp-30-3-0599 DOI: http://dx.doi.org/10.1590/0102-311X00090913

3. Camargos MCS, Marcos RG. Viver mais e melhor? Estimativas de expectativa de vida saudável para a população brasileira. Cad Saúde Pública [Internet]. 2015 jan/feb; [cited 2018 mar 09]; 31(7):14601472. Available from: http://www.scielo.br/scielo.php?pid=S0102311X2015000701460\&script=sci_abstract\&tlng=pt DOI: http://dx.doi. org/10.1590/0102-311X00128914
4. Reichert T, Prado AKG, Kanitz AC, Kruel LFM. Efeitos da hidroginástica sobre a capacidade funcional de idosos: metanálise de estudos randomizados. Rev Bras Ativ Fis Saúde [Internet]. 2015 sep; [cited 2016 jul 29]; 20(5):447-57. Available from: http://rbafs.org.br/RBAFS/ article/view/6177/5163 DOI: https://doi.org/10.12820/rbafs.v.20n5p447

5. Instituto Brasileiro de Geografia e Estatística (IBGE). Número de idosos no Brasil vai quadruplicar até 2060, diz IBGE. Rio de Janeiro (RJ): IBGE [Internet]. 2014; [cited 2016 jul 30]. Disponível em: http://www.ibge.gov. br

6. Ferreira JBS, Sá SPC, Pereira JPC, Santana RF, Domingos AM. Evaluation of psychomotor interventions in elderly with mild cognitive déficit. Ciênc Cuid Saúde [Internet]. 2016 jul; [cited 2017 aug 28] 15(3):538-545. Available from: http://www.periodicos.uem.br/ojs/ index.php/CiencCuidSaude/article/view/28666 DOI: http://dx.doi. org/10.4025/cienccuidsaude.v15i3.28666

7. Malachias MVB, Souza WKSB, Plavnik FL, Rodrigues CIS, Brandão AA, Neves MFT, et al. $7^{\text {a }}$ Diretriz Brasileira de Hipertensão Arterial. Arq Bras Cardiol. 2016 sep; 107(3 Suppl 3):1-83.

8. Reis LA, Reis LA, Torres GV. Impact of sociodemographic and health variables on the functional capacity of low-income elderly. Ciênc Cuid Saúde [Internet]. 2015 feb; [cited 2018 aug 13]; 14(1):847-854. Available from: http://periodicos.uem.br/ojs/index.php/CiencCuidSaude/ article/view/19585 DOI: http://dx.doi.org/10.4025/cienccuidsaude. v14i1.19585

9. Santos Júnior EB, Oliveira LPAB, Silva RAR. Chronic non-communicable diseases and the functional capacity of elderly people. J Res Fundam Care Online [Internet]. 2014 apr/jun; [cited 2016 mar 09]; 6(2):516525. Available from: https://www.redalyc.org/pdf/5057/505750622008. pdf DOI: 10.9789/2175-5361.2014v6n2p516

10. World Health Organization (WHO). International classification of functioning, disability and health [Internet]. Geneva: World Health Organization; 2007 jul/aug; [cited 2016 jul 29]. Available from: https:// www.who.int/classifications/icf/en/

11. Facchesatto A, Rockett FC, Perry IDS. Fatores de risco e proteção para o desenvolvimento de doenças crônicas em população idosa rural do Rio Grande do Sul. Rev Bras Geriatr Gerontol [Internet]. 2015 dec; [cited 2016 jul 28]; 18(4):779-795. Available from: http://www.scielo. br/pdf/rbgg/v18n4/pt_1809-9823-rbgg-18-04-00779.pdf DOI: http:// dx.doi.org/10.1590/1809-9823.2015.14150

12. César CC, Mambrini JVM, Ferreira FR, Costa MFL. Capacidade Funcional de idosos: análise das questões de mobilidade, atividades básicas e instrumentais da vida diária ia Teoria de Resposta ao Item. Cad Saúde Pública [Internet]. 2015 may; [cited 2018 mar 09]; 31(5):931945. Available from: http://www.scielo.br/pdf/csp/v31n5/0102-311Xcsp-31-5-0931 DOI: http://dx.doi.org/10.1590/0102-311X00093214

13. Reis CB, Jesus RS, Silva CSO, Pinho L. Health conditions of young and old elderly. Rev Rene [Internet]. 2016 feb; [cited 2018 aug 13]; 17(1):120 7. Available from: http://periodicos.ufc.br/rene/article/view/2613/2001 DOI: https://doi.org/10.15253/2175-6783.2016000100016

14. Wachs LS, Nunes BP, Soares UM, Facchini LA, Thumé E. Prevalência da assistência domiciliar prestada à população idosa brasileira e fatores associados. Cad Saúde Pública [Internet]. 2016 mar; [cited 2018 jun 12]; 32(3):e00048515. Available from: http://www.scielo. br/pdf/csp/v32n3/0102-311X-csp-32-03-e00048515.pdf DOI: http:// dx.doi.org/10.1590/0102-311X00048515

15. Instituto Brasileiro de Geografia e Estatística (IBGE). Censo demográfico 2013: Pesquisa Nacional por Amostra de Domicílio [Internet]. Rio de Janeiro (RJ): IBGE; 2016; [cited 2019 feb 18]. Available from: https://www.ibge.gov.br/estatisticas/sociais/populacao/9171pesquisa-nacional-por-amostra-de-domicilios-continua-mensal.html

16. Brito KQD, Menezes TN, Olinda RA. Functional disability and socioeconomic and demographic factors in elderly. Rev Bras Enferm [Internet]. 2015 jul/aug; [cited 2018 aug 20]; 68(4):633-41. Available from: http:// www.scielo.br/pdf/reben/v68n4/0034-7167-reben-68-04-0633.pdf DOI: http://dx.doi.org/10.1590/0034-7167.2015680409i 
17. Silva CSO, Barbosa MMS, Pinho L, Figueiredo MFS, Amaral CO, Cunha FO, et al. Family Health Strategy: relevance to the functional capacity of older people. Rev Bras Enferm [Internet]. 2018 jan/feb; [cited 2019 feb 19]; 71(Suppl 2):740-6. Available from: http://www.scielo.br/pdf/ reben/v71s2/pt_0034-7167-reben-71-s2-0740.pdf DOI: http://dx.doi. org/10.1590/0034-7167-2017-0078

18. Kagawa CA, Corrente JE. Analysis of elderly functional capacity in the municipality of Avaré, São Paulo: associated factors. Rev Bras Geriatr Gerontol [Internet]. 2015 sep; [cited 2017 jun 12]; 18(3):577-86. Available from: http://www.scielo.br/pdf/rbgg/v18n3/en_1809-9823-rbgg-18-03-00577. pdf DOI: http://dx.doi.org/10.1590/1809-9823.2015.14140

19. Santos I, Guerra RGM, Silva LA. Categorias de autocuidado entre pessoas idosas com diabetes: estudo sociopoético. Rev Enferm UERJ [Internet]. 2015 mar/apr; [cited 2018 Mar 10]; 23(2):216-21. Available from: http://www.facenf.uerj.br/v23n2/v23n2a12.pdf DOI: http://dx.doi. org/10.12957/reuerj.2015.16498

20. Santos GS, Cunha ICKO. Avaliação da capacidade funcional de idosos para o desempenho das Atividades instrumentais da vida diária: um estudo na atenção básica em saúde. R Enferm Cent O Min [Internet]. $2013 \mathrm{sep} / \mathrm{dec}$; [cited $2018 \mathrm{apr}$ 12]; 3(3):820-28. Available from: http://www.seer.ufsj.edu.br/index.php/recom/article/view/421 DOI: http://dx.doi.org/10.19175/recom.v0i0.421
21. Jacobi CS, Beuter M, Girardon-Perlini NMO, Schwartz E, Leite MT, Roso CC. Family dynamics of elderly members undergoing predialysis treatment. Esc Anna Nery [Internet]. 2017; [cited 2018 aug 20]; 21(1):e20170023. Available from: http://www.scielo.br/pdf/ean/ v21n1/en_1414-8145-ean-21-01-e20170023.pdf DOI: 10.5935/14148145.20170023

22. Rosa TEC, Benício MHDA, Latorre MRDO, Ramos LR. Fatores determinantes da capacidade funcional entre idosos. Rev Saúde Pública [Internet]. 2003 feb; [cited 2017 jun 12]; 37(1):40-48. Available from: http://www.scielo.br/pdf/rsp/v37n1/13543.pdf DOI: http://dx.doi. org/10.1590/S0034-89102003000100008

23. Carnaúba CMD, Silva TDA, Viana JF, Alves JBN, Andrade NL, Trindade Filho EM. Clinical and epidemiological characterization of patients receiving home care in the city of Maceió, in the state of Alagoas, Brazil. Rev Bras Geriatr Gerontol [Internet]. 2017 may; [cited 2018 mar 10] 20(3):352-62. Available from: http://www.scielo.br/pdf/rbgg/v20n3/18099823-rbgg-20-03-00352.pdf DOI: http://dx.doi.org/10.1590/198122562017020.160163 